BOOK REPORT: THE DRAGON'S GIFT: THE REAL STORY OF CHINA IN AFRICA

\title{
THE DRAGON'S GIFT: THE REAL STORY OF CHINA IN AFRICA
}

\author{
Deborah Brautigam , The American University ${ }^{1}$
}

The Beijing Summit of the Forum on China-Africa Cooperation, held in November of 2006 helped to focus more world attention on the state of the African economy, which has seen far too many worries and failures and far too few successes. As the author states "It forced the West to focus on something new: Chinese aid and other forms of economic engagement were sharply on the rise in Africa. China was on a track to become the African continent's largest trading partner, outpacing Great Britain and the United States. Nearly 900 Chinese companies had invested in Africa by then (2002) - in factories and farms, retail shops and oil wells."

By the time of the summit, China's accelerated move into Africa was already a decade old, and Dr. Brautigam proves, by her really dazzling knowledge of both Africa and China, that China's presence is never - ever simple or single minded. China has been active in Africa for more than 50 years, and that presence has shifted and evolved in rough congruence with tides running in China itself. Brautigam quite rightly argues that Western observers, especially politicians, media, and academics are prone to lock onto a few simplistic themes which they endlessly quote to each other:

1. China is only after oil and other natural resources

2. Chinese money is always referred to as "aid"

3. China is propping up vicious regimes such as Sudan and Zimbabwe

4. China hurts efforts to promote democracy and human rights

5. China is making corruption worse

6. China relies too much on unfair subsidies such as subsidized loans or export credits

7. Chinese enterprises neglect or ignore environmental and social values and standards

8. Chinese loans to African countries is just adding to unsustainable debt burdens.

While conceding the elements of truth in each of these assertions, Brautigam enthusiastically debunks each of them. She points out time and time again the shallowness of such assessments which lead to misconceptions that are then passed from mouth to mouth as revealed truth.

\footnotetext{
${ }^{1}$ Brautigam, Deborah, "The Dragon's Gift: the Real Story of China in Africa", the Oxford University Press, 2009.
} 
Perhaps the most popular of these misconceptions is that which asserts that all flows of Chinese funds into Africa are "aid". Most people think of foreign aid as money given by one government to another to promote economic and social development, with military aid a separate adjunct of this government-togovernment policy. Yet huge amounts of money flow for other reasons. A lot of Chinese activities in Africa are essentially business transactions. Some are bids by Chinese enterprises in response to contract tenders. Others involve the formation of business joint ventures between African and Chinese enterprises. Some are the creation of new or expanded Chinese owned businesses in Africa. Others are Chinese purchases of stocks or bonds in African companies. Some are Chinese enterprises that are invited to manage African public sector facilities such as power stations, railroads or communication systems. All of these business ventures may have political or social dimensions, but they remain essentially that - business ventures.

Brautigam also asks her readers to consider two other views about China in Africa. First, she suggests that there is little that China is doing, good or bad, that has not also been done by Europeans, Americans, Japanese or Russians; and all of the criticisms and dark suspicions of China's motives or tactics have also descended on other nations.

Second, although she seems reluctant to do so, Brautigam gently points out that most of the sins of omission and commission in Africa are committed by African governments themselves. If China - and others - are accused of propping up tyrants, and encouraging corruption, it must be admitted that there are all too many tyrants and plenty of native corruption to go around. The worst that can be said is that corruption is so virulent in China itself that one must feel that the great bulk of deals between Africans and Chinese will be badly bent in some way.

Time and time again, Brautigam refutes the simplistic assertion that China has some "master strategy" to achieve control in Africa. If there is any coherent strategy it is more about China than about Africa, and key to any such strategy is the condition of China's State Owned Enterprises (SOE).

After WW II, many governments around the world including China, turned to state socialism in various forms. While private companies were not trusted or favored, the socialist governments still had to operate organizations to produce goods and services. The kind of institution that emerged was generally called the State Owned Enterprise (SOE). SOEs were an innovation in that they were neither private companies nor standard government agencies, but were sort of half-way independent and were capable of economic activities including 
manufacturing and retailing for which standard bureaucracies were not suitable. The essence however -always - was that the SOEs would remain instruments of the government and would remain under government control.

Gradually however, governments began to recognize that SOEs were proving to be a failed experience, and all too many were inefficient, increasingly obsolete, and had been operating at substantial deficits. Governments that had counted on deriving larger revenues from their SOEs found instead that significant numbers of them were losing money and had to be subsidized and propped up using funds that had to be diverted from other priorities.

Why did the SOEs prove to be a failed experience? Most critically, the basic concept itself proved to be flawed, in that SOEs had too little real independence and far too much political intervention which proved to be seriously stifling, debilitating and often corrupt.

The watershed over the fate of Chinese SOEs occurred in 1998, when the order was issued to initiate the massive program of what is termed SOE divestiture. From an estimated major 75,000 SOES the goal is to keep only 23,000. But it turned out that "divestiture" was not the same thing as "privatization". Many strategies for divestiture were developed. In many cases, the preferred approach of the government has been not to divest at all, but to attempt to upgrade the performance of the SOEs it wished to retain. This retention approach was particularly important in what can be called the "commanding heights" sectors of the economy - those sectors that drive or control many other sectors. In many cases, whole sectors of the Chinese economy have been restructured through mergers and acquisitions, consolidations, combinations, and "thinning out". In other instances, the preferred strategy with retained SOEs has been to seek to partner them with solid private sector enterprises, either Chinese or foreign invested.

So it remains true today that the Chinese Communist Party (CCP) and government relies heavily on their SOEs, along with state owned banks, to control and channel the Chinese economy, and these SOES are too important to fail. China's government is using the opportunities in Africa to expand the range of its SOEs, and give them valuable experience in operating in the global economy in Africa where failure would not damage the heartland.

Dr. Brautigam identifies many Chinese enterprises by name. They may be called "companies" or "corporations" or "groups", but in fact they are mostly state owned and/or controlled enterprises under the direct and demanding control of the Chinese government and Chinese Communist Party. Of 38 Chinese enterprises identified in Africa by name, it appears that 27 of them are SOEs, 
including 12 huge engineering enterprises. In addition, some of the private companies benefit from forms of support or subsidy from the Chinese government. And so the question arises: how much subterranean direction and "guidance" comes out of Beijing through these SOEs and client companies, and to what effect? Brautigam doubts that China has any single grand strategy, and she is surely right, but it may be that it has several loosely related economic sector strategies (pharmaceuticals, communications, public infrastructure, agriculture), each shaped to some degree by CCP direction.

Even if this were to be true, it would not necessarily be ominous. For example, there is nothing wrong if the Chinese government assists its SOEs to build one or more pharmaceutical manufacturing plants in Africa, hoping to capture a significant share of the continental market. Yet this example can also be used to illustrate how a perverse Chinese government could go wrong. First, the government could subsidize these plants so extensively that no other rivals, domestic or foreign, could compete with them. Would the Chinese government ever do such a thing? Of course it might, it has done so extensively in China itself to quash private sector competitors to some cherished SOE. The crucial point is this: for long periods of time, China's SOEs were so poorly managed that $50 \%$ of them were operating at deficits, and others were making only razor thin profits. They had to be propped up repeatedly and expensively by the Chinese government. Finally, the 1998 divestiture program was launched that purged thousands of losers. During this process, the government consolidated, rationalized, purged, restructured and refinanced the remaining enterprises. China now says it has 2,000-3,000 SOEs; but many have in fact emerged as huge new holding companies, some with hundreds of subsidiaries, backed by the almost unlimited resources of the Chinese government and its banks, the most important of which are themselves SOEs. Clearly, China cannot afford to have these SOEs fail again, and the government will do everything in its power to make them succeed.

And so, many of these huge conglomerates have been showing up in Africa to do business, and the Chinese government itself has a high stake in their success or failure. Thus, the Chinese government has been using its extraordinarily broad power more directly by dealing with the leaders of African governments and offering them many inducements such as direct governmentto- government loans, often at very low interest rates; or allowing African goods into China duty free; or all of the other attractions and concessions that Dr. Brautigam explains so clearly.

Thus, China's strategic imperative does not seem to be to "take over Africa" so much as it is to do whatever it must to make it state owned enterprises succeed. One of the new imperatives, as Dr. Brautigam points out, is to let these 
SOEs have a greater degree of latitude in deciding which business opportunities to pursue, and in what way. This really means that the CCP and ministries of government have got to constrain their urge to apply the kind of political meddling that got the SOEs in such trouble in China itself. In addition, or perhaps in consequence, the new generation of SOE managers in Africa seem remarkably better than their predecessors. African leaders and even Western donors are now more ready to agree that most projects pursued by Chinese enterprises are going to be successfully undertaken, and that is all to the good. Western donors, and the Africans themselves are tired of watching oceans of money dissipated by corruption and bumbling incompetence, disappearing like rain on the face of the desert.

It is probably true that the Chinese government makes choices of which of its SOEs it will deploy, and in what sectors of the African economy. But again, Dr. Brautigam urges that this is not unusual nor need it be seen as ominous. Other governments and donors, and even private companies, make the same kinds of decisions, and nobody thinks they are trying to take over Africa. "China is already changing rapidly, with Chinese leaders moving away from old alliances (Mugabe in Zimbwabwe for example), and stepping into an unaccustomed new role as a mediator in the Sudan. Chinese naval patrols were rescuing European ships in the pirate infested waters off the coast of Somalia. New domestic pressures for enterprise social responsibility and environmental and social responsibilities were growing inside China. New laws were put in place for labor rights in China, new guidelines published outlining the environmental and social responsibilities of banks and forestry companies overseas."

It is difficult to track how effectively these changes are taking place in Africa, just as it is in China itself. But certainly, the tides are running against any theory of Chinese takeover conspiracy. If Dr. Brautigam can't find conspiracy, nobody can. She avoids boiling things down to headlines, but her conclusion is that China in Africa is a surprisingly good thing. 